\title{
Radiotherapy-Induced Salivary Hypofunction: An Update on the Preventive Mechanisms
}

\author{
Luísa Gallo DA, Antonia Zancanaro FM, Karen C, Gonçalves SF* \\ Oral Medicine Division, Brazil \\ *Corresponding author: Fernanda Gonçalves Salum, Oral Medicine Division, Hospital São Lucas, BrazilUSA
}

Submission: 眥 January 10, 2018; Published: 眥 January 18, 2018

\begin{abstract}
Head and neck radiotherapy is one of the main causes of salivary dysfunction. The salivary glands are extremely sensitive to ionizing radiation, presenting irreversible structural alterations, with alterations in salivary flow and composition. The present study aimed to provide an update on the mechanisms of prevention of the radiotherapy-induced salivary hypofunction through an integrative literature review. Pre-clinical studies in animal models, controlled clinical trials and meta-analysis were selected. Preventive pharmacological methods were approached such as the use of cholinergic agonists (pilocarpine and bethanechol), antioxidant substances, acupuncture, low-level laser therapy (LLLT) and submandibular gland transfer. Studies with bethanechol, pilocarpine and amifostine corroborate the prophylactic effect of these drugs on the salivary glands. However, they have side effects which contraindicate its use in several patients. Researches about acupuncture and LLLT show preservation of salivary flow in oncologic patients with no or little side effects. Patients who undergo the submandibular gland transfer technique previously to radiotherapy also have less incidence of xerostomia. In general, the therapies presented in this review can help to prevent the symptoms caused by the hypofunction of the irradiated salivary glands. Nevertheless, at this point there are no techniques or drugs capable of completely preventing the development of radiotherapy-induced salivary dysfunctions. Controlled clinical trials are still needed in order to find therapeutical methods that preserve the glandular structure undergoing ionizing radiation, thus preventing hyposalivation and xerostomia..
\end{abstract}

Abbreviations: Salivary gland; Radiotherapy; Radioprotector; Xerostomia; Hyposalivation

\section{Introduction}

The saliva is a fluid of extreme importance in the maintenance of oral homeostasis, being present in several biologic processes. It is composed in almost its totality by water and electrolytes, besides proteins such as immunoglobulins and mucins. This fluid acts in the lubrication of the mucosa, digestion, phonation, gustation, neutralization of acid components and in the immune systems through antimicrobial peptides against bacteria, fungi and viroses [1-5]. Hyposalivation is characterized by the decrease in the capacity of the salivary glands to secrete saliva, and xerostomia is defined as the subjective sensation of oral dryness. Such alterations can be caused by drugs, systemic diseases, head and neck radiotherapy, among other reasons [6]. Patients affected by salivary dysfunctions tend to show an atrophic oral mucosa, as well as symptoms such as dysphonia, dysphagia, oral burning sensation and palate alterations. There is increased risk to oral candidiasis, caries lesions and periodontal alterations [7-9]. The diminished bactericidal effect of saliva favors the increase of population of the microorganisms responsible for these diseases [8,10]. Head and neck radiotherapy is one of the main causes of salivary dysfunction $[11,12]$. The major salivary glands are usually included in the radiation portals due to the fact that they reside close to primary tumor sites and lymphatic chains of the head and neck region and frequently have their function impaired resulting in hyposalivation and xerostomia [11,13-15]. Among the radiotherapy methods most employed in head and neck region, conventional 2D radiotherapy (RC) is the one that presents the most significant side effects on the glandular tissue. Intensity-modulated radiotherapy (IMRT) and three dimensional conformal radiotherapy (3DCRT) reduce the radiation dose on the health structures close to the tumor and, consequently, the toxicity caused by the ionizing radiation $[13,16$ 20]. The salivary glands are extremely sensitive to ionizing radiation, presenting structural alterations which cause changes in salivary flow and composition [21]. These alterations are dose-dependent and can be irreversible [21,22]. Permanent hyposalivation is frequently associated to doses of $\geq 50$ Gy, usually used for head and neck cancer treatment [23].

Irradiated patients often present salivary flow lower than users of drugs which cause xerostomia and of patients with Sjögren syndrome [24]. Many studies have investigated the effects of radiotherapy on the morphology of salivary glands. Among the microscopic and ultrastructural acute alterations there are hypovascularization, cytoplasmic vacuolation, pleomorphism, nuclear condensation, and damage to mitochondria and to cell membranes of acinar cells. Later there are phenomena such as 
inflammation, as well as duct dilatation, vascular congestion, decrease in the number of acinar cells and in the glandular volume, increase in adipose and fibrous tissues, with atrophy and parenchymatous degeneration [25-30]. The irradiated salivary glands can present a reduction of approximately $50 \%$ of their weight in comparison to non-irradiated glands [21,25]. Studies have been conducted in order to find agents capable of preventing the sequelae caused by ionizing radiation on salivary glands [3035]. Several modalities such as the use of antioxidant substances (vitamins and resveratrol), selective agonists of muscarinic receptors, submandibular gland transfer, acupuncture, lowlevel laser therapy [34,36-41] have been investigated in clinical and laboratory studies in prevention of radiotherapy-induced xerostomia. The level of decrease in salivary flow post-radiotherapy is dose-dependent and this effect can be aggravated with time [32]. The best treatment for radiotherapy-induced hyposalivation is prevention since radiotherapy can cause irreversible damages to glandular tissues. Thus, the present study aimed to review and provide an update in mechanisms for prevention of radiotherapyinduced salivary hypofunction. An integrative literature review was conducted in Medline/PubMed/Lilacs/Bireme databases using the terms "radiotherapy", "intensity-modulated radiotherapy", "xerostomia", "hyposalivation", "radiation-protective agents", "amifostine", "bethanechol", "pilocarpine", "vitamin E", "resveratrol", "acupuncture", "low level laser therapy" and "submandibular gland transfer". Pre-clinical studies in animal models, meta-analysis and controlled clinical trials with preventive character on salivary glands were selected and analyzed. Proper references of these papers were also reviewed.

\section{Radioprotective drugs}

In order to be considered radioprotective, the substance must have the capacity to protect the tissues without causing genetic alterations, mutations, damages to the immune system or toxicity [29]. Many drugs have been tested, among which the most quoted in literature are the cholinergic agonists, such as pilocarpine and bethanechol, and the antioxidant substances.

Bethanechol: Bethanecol is a parasympathomimetic drug, selective agonist of muscarinic receptors of the parasympathetic nervous system, which stimulates the secretory function. ${ }^{37,42}$ This drug is widely employed in the treatment of postoperative urinary retention and has been studied in xerostomia treatment, showing good results. When employed for xerostomia, the recommended dose is of $25-50 \mathrm{mg}$ twice to three times a day $[37,42,43]$. Jham et al. [19] assessed the effect of bethanechol in the prevention of xerostomia in a clinical trial with 43 patients irradiated on the head and neck regions. One group used bethanechol, $25 \mathrm{mg}$, three times a day, and the other used artificial saliva during the oncological treatment. The major salivary glands received an amount of at least $45 \mathrm{~Gy}$ of radiation. In the bethanechol group, the salivary flow not stimulated was of $0.30 \mathrm{ml} / \mathrm{min}$, significantly different from the control group, which was of $0.18 \mathrm{~min} / \mathrm{ml}(\mathrm{p}=0.03)$. Furthermore, the participants of the bethanechol group reported less symptoms, with lower values in the xerostomia $(\mathrm{p}=0.05)$ (Table 1$)$. In a double-blind study, bethanechol was used in 42 patients, from the beginning until one month after radiotherapy. The 3DCRT and the IRMT techniques were used in both groups, bethanechol and control. The group that used bethanechol presented an improvement in saliva production both in resting $(\mathrm{p}=0.008)$ as well as under stimulation $(\mathrm{p}=0.005)$ in comparison to the placebo group. Besides, the prevalence of grade III xerostomia was lower $(p=0.004)$ in the group that received bethanechol, even three months after the end of radiotherapy [43]. The side effects reported by the patients that used bethanechol were facial burning sensation, muscle cramps, nervousness, diarrhea, nausea, lacriamation, frequent urination and excessive sweating [37]. Bethanechol is contraindicated in cases of hyperthyroidism, peptic ulcer, asthma, coronarian arterial disease, gastrointestinal diseases, bradicardia, hypotension, vasomotor instability, epilepsy and Parkinson disease [44].

Table 1: Clinical trials investigating the effects of pilocarpine in radiotherapy-induced xerostomia and hyposalivation prevention in patients with head and neck cancer.

\begin{tabular}{|c|c|c|c|}
\hline Authors & Groups and Radiation Doses & Pilocarpine & Results \\
\hline \multirow[b]{3}{*}{$\begin{array}{l}\text { Zimmerman et } \\
\text { al.[27] }\end{array}$} & CR+Placebo $(n=18)$ & \multirow{3}{*}{$\begin{array}{l}5 \mathrm{mg}, 4 \mathrm{X} \text { a day, orally, } \\
\text { during radiotherapy and } \\
\text { until } 3 \text { months after. }\end{array}$} & \multirow[b]{3}{*}{$\begin{array}{l}\text { Less symptoms of xerostomia reported in the Pilocarpine } \\
\text { group }(\mathrm{p}<0.01) .\end{array}$} \\
\hline & CR+Pilocarpine $(n=22)$ & & \\
\hline & $50-74 G y \geq 45 G y$ in parotid glands & & \\
\hline \multirow{3}{*}{$\begin{array}{l}\text { Haddad \& Karimi } \\
\qquad[28]\end{array}$} & CR+Placebo $(n=29)$ & \multirow{3}{*}{$\begin{array}{l}5 \mathrm{mg}, 3 \mathrm{X} \text { a day, orally, } \\
\text { during radiotherapy and } \\
\text { until } 3 \text { months after. }\end{array}$} & \multirow{3}{*}{$\begin{array}{l}\text { Six months after radiotherapy the Pilocarpine group pre- } \\
\text { sented better results with significant differences both in } \\
\text { the subjective }(\mathrm{p}=0.02) \text { as well as in the objective }(\mathrm{p}=0.01) \\
\text { xerostomia criteria analysis. }\end{array}$} \\
\hline & CR+Pilocarpine (n=31) & & \\
\hline & 45-70Gy $\geq 40$ Gy in parotid glands & & \\
\hline
\end{tabular}




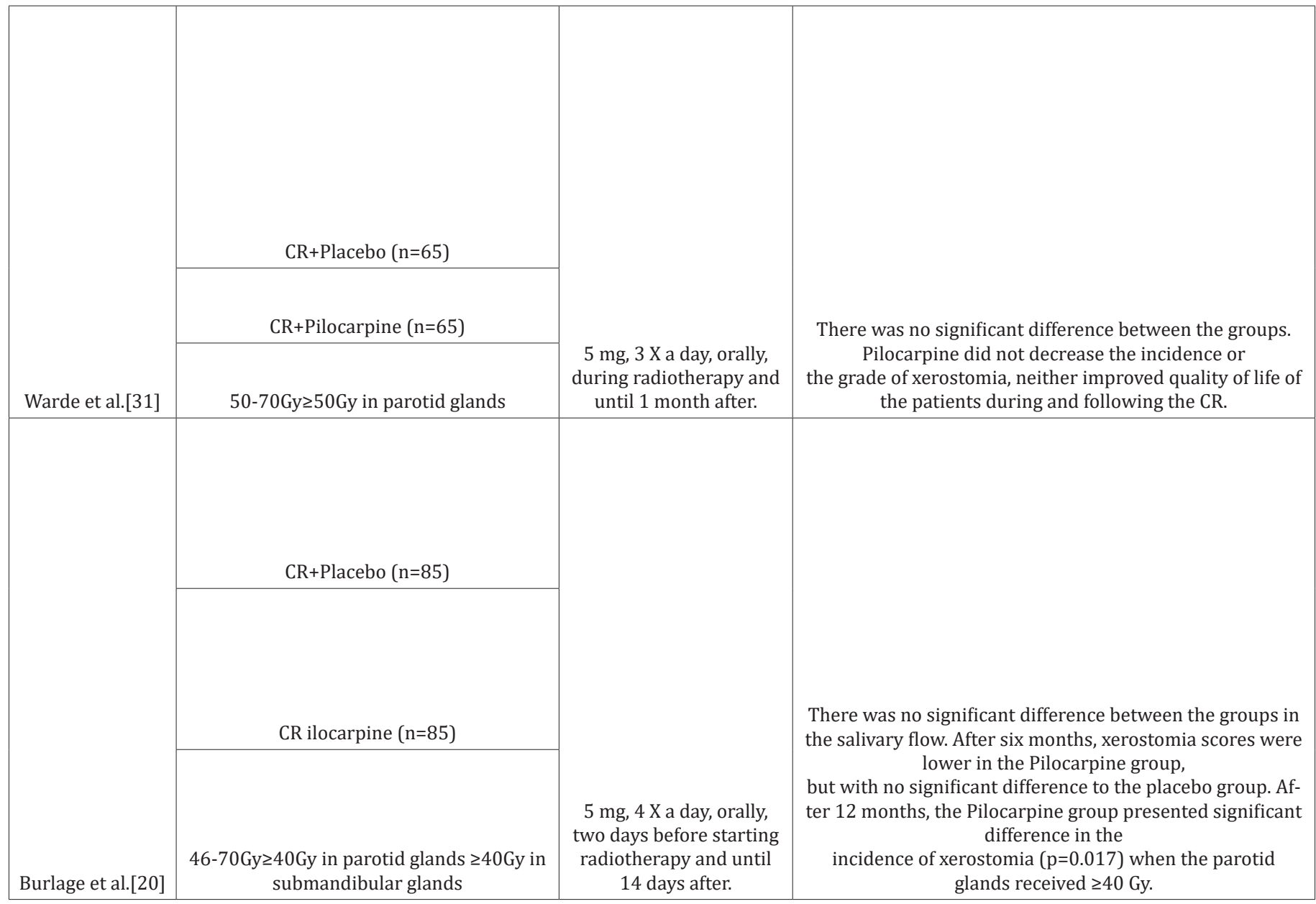

Pilocarpine: Pilocarpine is a drug which stimulates glandular function also through the activation of cholinergic muscarinic receptors $[11,42]$. Studies have demonstrated favorable results in xerostomia prevention in patients who undergo radiotherapy $[38,45,46]$. Pilocarpine must be ingested in small doses, usually of $5 \mathrm{mg}$ from three to four times a day ${ }^{47}$ with a maximum daily dose of $30 \mathrm{mg}$ [11]. Its effect against hyposalivation is immediate, and can last up to four hours. Nonetheless, when used in patients postradiotherapy of head and neck, its effect can take up to 12 weeks to occur [11]. Zimmerman et al. [27] observed that the patients that received this drug during radiotherapy and in the three months following it showed less symptoms of xerostomia.

In a meta-analysis, Yang et al. [29] reviewed the use of pilocarpine as a method for radiotherapy-induced xerostomia prevention. The analyzed studies showed that pilocarpine increased the non-stimulated salivary flow in the first 12 months of follow-up. The authors concluded that pilocarpine can improve the quality of life of irradiated patients. However, since it is a cholinergic drug, patients can present side effects such as nausea, lacrimation, sweating, frequent urination, rhinitis, low intensity headache and gastrointestinal disturbs. Pilocarpine is contraindicated for patients with chronic diseases such as asthma, cardiopathies, epilepsy, angle-closure glaucoma, hypothyroidism, Parkinson disease and anyone using other adrenergic antagonist drugs or drugs with parasympathomimetic or anticholinergic effects [42,46-49].
Amifostine: Amifostine has been researched since the 1950 decade for the prevention of damages to tissues adjacent to tumors treated through radiotherapy and chemotherapy, because it has antioxidant properties, acting against free radicals. The American Society of Clinical Oncology (ASCO) and the US Food and Drug Administration (FDA) recognized its radioprotective effect on healthy cells [50]. Table 2 shows clinical trials assessing the radioprotective effect of amifostine in patients with head and neck cancer. The effect of amifostine in the prevention of salivary alterations was assessed through meta-analysis that included 1167 patients with head and neck cancer who underwent radiotherapy or radiochemotherapy. Amifostine prevented chronic and acute xerostomia in irradiated patients. In patients treated through chemotherapy and radiotherapy, amifostine prevented chronic xerostomia, but it was not effective on acute xerostomia [51]. The side effects that patients using amifostine can present during oncologic treatment are arterial hypotension, nausea, vomits, asthenia, fever, mucositis, tachycardia, bronchitis, allergic reaction and rash $[33,52,53]$. The higher the applied dose, the more severe the side effects related to amifostine. Furthermore, chemotherapeutic drugs can increase this drug's toxicity [52,53]. Patients allergic to products of aminothiol and manitol basis, pregnant or breastfeeding women, people older than 70 and younger than 18 years old, people that are dehydrated, who are using antidepressant drugs or drugs that trigger hypocalcemia, who present cardiovascular or 
cerebrovascular diseases, severe renal or hepatic impairment or hypocalcemia risk are contraindicated for the use of amifostine

Table 2: Clinical trials assessing the effect of amifostine in the prevention of radiotherapy-induced xerostomia and hyposalivation in patients with head and neck cancer.
$[54,55]$. Although it is widely studied, amifostine still has not had its mechanism of action completely clarified [56].

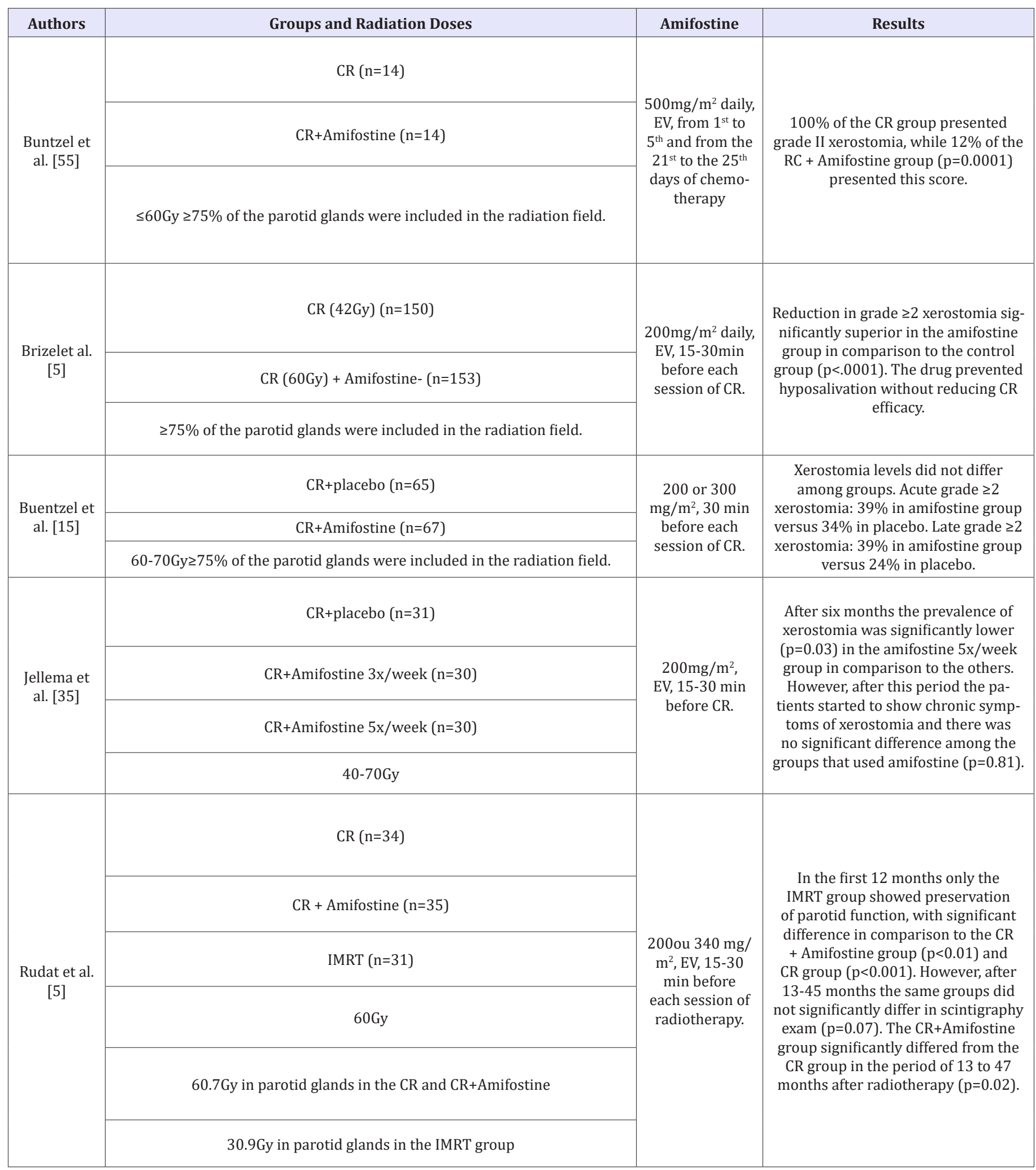

CR: Conventional Radiotherapy), IMRT: Intensity-Modulated Radiotherapy; EV: Endovenous 
Vitamin E: Due to its high antioxidant power, vitamin E ( $\alpha$-Tocopherol) has been analyzed as a radioprotective agent in the small bowel, thyroid gland and salivary glands [30,36,57-59]. Ramos et al. [18]. analyzed the radioprotective effect of vitamin E in salivary glands of irradiated rats (15Gy). Vitamin E was administered in doses of $360 \mathrm{mg} / \mathrm{kg}, 24,48$ and 72 hours before radiotherapy. After 30 days of radiotherapy, a recuperation of salivary flow was observed in the irradiated animals that had received vitamin $\mathrm{E}$, suggesting late protection over the salivary glands. Gomes et al [40]. did not observe differences in the number of acinar cells between animals treated with vitamin $\mathrm{E}$ and placebo 30 days after the radiotherapy (15Gy).On the other hand, Abedi et al.[12], in a study with rats, demonstrated that microscopic alterations in irradiated parotid glands, such as vacuolation, ductal dilatation, vascular congestion, lysis of acinar cells and fibrosis were less evident in the animals treated with vitamin E. Chitra et al. [42] analyzed the salivary flow, pH levels, salivary amylase, sodium, potassium and salivary total protein concentration in the saliva of irradiated patients $(n=89)$ who received vitamin E simultaneously to radiotherapy. Patients received $400 \mathrm{UI} /$ day of vitamin E, orally, during three or six weeks (five days a week). There was no decrease in salivary flow in comparison to the beginning of the treatment after the three first weeks of radiation. On the other hand, the irradiated control group had a significant decrease of the salivary flow in the same period $(\mathrm{p}<0.001)$. After six weeks of radiotherapy, patients that used vitamin $\mathrm{E}$ presented higher levels of $\mathrm{pH}$, salivary flow, potassium $(\mathrm{p}<0.001)$, salivary amylase activity $(\mathrm{p}<0.01)$, proteins and sodium $(\mathrm{p}<0.05)$, in comparison to the control group. In a prospective, randomized, double-blind, placebo-controlled study, Chung et al. [17] assessed the radioprotective effect of vitamins $C$ and $\mathrm{E}$ on salivary glands in 45 patients with head and neck cancer. A pill containing $100 \mathrm{UI}$ of vitamin $\mathrm{E}$ and $500 \mathrm{mg}$ of vitamin $\mathrm{C}$ was given twice a day, beginning one week before radiotherapy until one month after. IMRT technique was used, the average radiation dose on the parotid glands was of 12Gy for the control group and $14 \mathrm{~Gy}$ for the group that took the vitamins. In the submandibular glands, the radiation dose was of 25Gy and 23Gy in the two groups, respectively. The xerostomia scores were high one month after the end of radiotherapy in both groups; however, in the patients that used the vitamins there was significant reduction of these scores after five months. The study showed that the use of vitamins $\mathrm{C}$ and $\mathrm{E}$ had a beneficial effect in patients irradiated on head and neck, preserving part of the salivary function.

Resveratrol: Resveratrol is a polyphenolic substance mainly found in the red wine, in the red grape skin and also in peanuts. It is known for its antiinflammatory, antioxidant, vasodilating, antitumoral, anti-aging, among other properties. Moreover, it is related to the modulation of transcription factors, inhibition of kinase proteins, suppression of antiapoptotic genes and inflammation mediators [43]. Some studies suggest that resveratrol can present radioprotective potential $[28,44]$. In irradiated rats, resveratrol diminished apoptosis and enhanced cell tolerance to oxidative stress in the hippocampus. In the presence of this substance, there was an increase in the activity of Sirt-1 enzyme. Şimșek et al [16] observed, in Wistar rats, that resveratrol in high dosages protected the salivary glands from the harmful effects of ionizing radiation. The animals underwent total body irradiation, in a single dose of 7.2Gy, 24h after the infusion of intraperitoneal resveratrol in doses of $10 \mathrm{mg} / \mathrm{kg}$ or $100 \mathrm{mg} / \mathrm{kg}$. The group that received $100 \mathrm{mg} / \mathrm{kg}$ of resveratrol showed a higher preservation of acinar structure and diminished necrosis in submandibular glands when compared to the group of $10 \mathrm{mg} / \mathrm{kg}$ or the control group ( $\mathrm{p}<0.05)$.

Another in vivo study evaluated salivary flow and morphologic and biochemical alterations in submandibular glands of mice who underwent radiotherapy and treatment with resveratrol. An intraperitoneal infusion of resveratrol was administered in doses of $20 \mathrm{mg} / \mathrm{kg}$ a day, in the three days before radiotherapy (15Gy) and 30 minutes before the procedure. Resveratrol prevented the radiotherapy-induced hypofunction in submandibular glands. Salivary flow in the animals that received resveratrol treatment was significantly higher in the $24 \mathrm{~h}(\mathrm{p}<0.01)$ and 30 days $(\mathrm{p}<0.05)$ periods after radiotherapy. Moreover, there was no significant drop in superoxide dismutase enzyme in the experimental group. In the histological evaluation of submandibular glands, eight hours after the irradiation, the control group presented modifications such as acinar vacuolization, nuclear alterations and inflammatory infiltrate. These were even more evident throughout time and, after 30 days, fibrosis was observed. Furthermore, the group that received resveratrol presented milder alterations in relation to vacuolization, inflammatory infiltrate, as well as the absence of fibrosis in all of the periods [10].

\section{Other radioprotective methods}

Other non-pharmacological methods for radioprotection of salivary glands have also been researched, such as acupuncture, low level laser therapy and submandibular gland transfer.

Acupuncture: Acupuncture is a possible method for prevention and treatment of xerostomia and hyposalivation associated to radiotherapy [45]. Braga et al. [22] in a study with irradiated patients $(n=24)$ in head and neck regions ( $\geq 50 \mathrm{~Gy})$, observed that acupuncture diminished the grade of xerostomia in comparison to the control group. Between 16 and 20 acupuncture sessions were performed along the whole anti-tumoral treatment, reaching local (ST-3, ST-4, ST-5, ST-6, ST-7, GB-2, SI-19, TB-21), distal (LI-4, LI-11, LR-3, ST-36, KI-3, KI-5, GV-20) and auricular points (Shen -Men, central nervous system, neurovegetative system, kidney, spleen, pancreas and mouth), totalizing 29 points in each session. Salivary flow, both in resting as well as under stimulation, was significantly higher in the acupuncture group $(\mathrm{p}<0.001)$. Moreover, the patients also complained less about oral mucosa burning sensation, pain and dysgeusia.

In a controlled study involving 86 patients irradiated on head and neck regions, Meng et al. [46] used acupuncture three times a 
week, concomitantly to radiotherapy (média de 71Gy). In the first 11 weeks after the end of treatment, the group that underwent acupuncture sessions presented salivary flow in resting and under stimulation significantly higher than the control group. Six months after the treatment there was no significant difference between the groups for salivary flow in resting. However, salivary flow under stimulation remained significantly superior in the acupuncture group. Furthermore, patients who underwent acupuncture sessions presented less xerostomia symptoms in comparison to the control group. In a systematic review, Zhuang et al. [45]. concluded that the acupuncture used to prevent xerostomia in patients with head and neck cancer has little or no side effects. Although studies suggest efficacy in combating xerostomia, there are still no clear evidences for the acupuncture to be considered a standard treatment in oncologic treatment centers.

Low Level Laser Therapy (LLLT): The effect of LLLT on salivary glands is a source of discussions in literature. There are few studies that support the effect of this therapeutic alternative on saliva's production and the modification of its composition. Studies suggest that low level laser, through photophysical and photochemical reactions, acts on cellular metabolism, inducing cellular proliferation and protein synthesis. According to the authors, LLLT can enhance local vascularization of irradiated salivary glands $[23,47,48]$. Acauan et al. [23] investigated the effect of LLLT in the prevention of radiotherapy-induced alterations in the parotid glands of mice. The LLLT $\left(830 \mathrm{~nm}, 100 \mathrm{~mW}, 0.028 \mathrm{~cm}^{2}\right.$, $3.57 \mathrm{~W} / \mathrm{cm}^{2}$ ) was applied punctually in the region of the parotid glands with the energy of $2 \mathrm{~J}\left(20 \mathrm{~s}, 71 \mathrm{~J} / \mathrm{cm}^{2}\right)$ or $4 \mathrm{~J}\left(40 \mathrm{~s}, 135 \mathrm{~J} / \mathrm{cm}^{2}\right)$ immediately before the radiotherapy session (10Gy) and $24 \mathrm{~h}$ after it. The method preserved acinar structure, reducing the incidence of vacuolization and apoptosis, mainly when the $4 \mathrm{~J}$ protocol was applied. Lopes et al. [49] in a controlled study, assessed LLLT's effect in the prevention of salivary glands hypofunction in 60 patients with head and neck carcinoma who underwent chemo and radiotherapeutic treatment.

The laser of InGaAlP $(685 \mathrm{~nm}, 35 \mathrm{~mW}$ ) was employed in doses of $2 \mathrm{~J} / \mathrm{cm}^{2}$ per point over the jugal mucosa, floor of mouth, tongue, tonsillar pillar, uvula, submandibular and parotid glands, during 58 seconds. Patients who underwent laser therapy presented stimulated and non-stimulated salivary flow close to normal, with significant difference $(\mathrm{p}<0.001)$ when compared to the control group. Gonnelli et al. [47] performed 21 sessions of laser therapy (InGaAIP) intra and extraoral, three times a week, in alternate days, during radiotherapy (66-70Gy) and chemotherapy (cisplatin $40 \mathrm{mg} / \mathrm{m}^{2}$ weekly) in head and neck cancer patients $(\mathrm{n}=23)$. For the intraoral application, a $660 \mathrm{~nm}$ wavelenght, $40 \mathrm{~mW}$ potency and $10 \mathrm{~J} / \mathrm{cm}^{2}$ dose for 10 seconds per point were employed. For the extraoral application, a $780 \mathrm{~nm}$ wavelenght, a $15 \mathrm{~mW}$ potency and a $3,8 \mathrm{~J} / \mathrm{cm}^{2}$ dose for 10 seconds per point was used. Saliva production with or without stimulation was assessed previously to the first radiochemotherapy session and 30 days after the last session. Salivary flow, both in resting $(\mathrm{p}=0.014)$ as well as under stimulation $(\mathrm{p}=0.013)$ was significantly higher in the laser group. In another study, Gonnelli et al. [48] using the same described parameters, evaluated the effect of LLLT in non-stimulated saliva production in patients with head and neck cancer $(n=27)$ treated with radiotherapy (66-70Gy) and chemotherapy. The patients were evaluated in different periods: before radiotherapy, after 15 sessions, after the last session, 30 and 90 days after the end of treatment. Patients of the laser group showed salivary flow significantly higher than the control group after the $15^{\text {th }}$ session of radiotherapy $(p=0.015)$, at the end of the radiochemoterapy treatment $(p=0.014)$ and 30 days $(p=0.023)$ after the conclusion of the oncological treatment. Nevertheless, after 90 days from the end of treatment, there was no significant difference between the groups regarding salivary flow.

Submandibular gland transfer: Submandibular gland transfer (SGT) is also a procedure used to prevent salivary glands hypofunction, improving the quality of life of the patients that will undergo radiotherapy on head and neck regions [50]. It is performed through a surgical procedure of transferring the submandibular gland to the submental region. The SGT is indicated for patients with primary tumors of the posterior region of the oral cavity, oropharynx, nasopharynx and larynx who do not have impaired lymph nodes. In the Table 3 are described clinical trials assessing the effect of submandibular gland transfer in the preservation of salivary flow in patients irradiated in the head and neck region. Sood et al [51]., through a meta-analysis, investigated the incidence of xerostomia, maintenance of salivary flow (during and after radiotherapy) and perception regarding the maintenance of glandular function in patients who underwent submandibular gland transfer. In $82.7 \%$ of 177 cases, SGT prevented radiotherapyinduced xerostomia. Nevertheless, ionizing radiation decrease both stimulated and non-stimulated salivary flow 2-3 months after the end of radiotherapy. However, after 10-12 months there was a salivary recovery, reaching $76 \%$ of stimulated and $88 \%$ of non-stimulated flow in comparison to the baseline. Wu et al. [52] also investigated through meta-analysis the effect of SGT on radiotherapy-induced xerostomia. Twelve studies were analyzed, in which 369 patients were treated. The SGT was capable of reducing in $69 \%$ the incidence of acute xerostomia and in $81 \%$ of chronic xerostomia. The SGT does not interfere in the efficacy of the oncological treatment. After five years of follow-up, there is no significant difference in survival rate of patients who underwent or did not underwent SGT $[52,53]$. Yet, this kind of procedure also have disadvantages. The patient must undergo surgery, which can lead to complications, and needs pre and postoperative care. Moreover, the described method is only applied to submandibular glands. 
Table 3: Clinical trials assessing the effect of submandibular gland transfer (SGT) in the prevention of radiotherapyinduced xerostomia and hyposalivation in patients with head and neck cancer.

\begin{tabular}{|c|c|c|c|}
\hline Authors & Groups and Radiation Doses & SGT & Results \\
\hline \multirow{4}{*}{$\begin{array}{l}\text { Seikaly et } \\
\text { al. [56] }\end{array}$} & CR $(n=12)$ & \multirow{4}{*}{$\begin{array}{l}\text { Surgery performed 4-6 } \\
\text { weeks before the CR. }\end{array}$} & \multirow{4}{*}{$\begin{array}{l}\text { After } 2 \text { years of radiotherapy, the SGT group still presented salivary } \\
\text { flow significantly superior to the control group }(\mathrm{p}<0.005) \text {. }\end{array}$} \\
\hline & & & \\
\hline & CR+SGT (n=26) & & \\
\hline & 50-70Gy & & \\
\hline \multirow{3}{*}{$\begin{array}{c}\text { Jha et al. } \\
\text { [57] }\end{array}$} & $\mathrm{CR}+\mathrm{SGT}(\mathrm{n}=60)$ & \multirow{3}{*}{$\begin{array}{l}\text { Surgery performed 4-6 } \\
\text { weeks before the CR. } \\
\text { Pilocarpine: } 4 \text { X/day, from } 3 \\
\text { days prior to the CR until } 3 \\
\text { months after it. }\end{array}$} & \multirow{3}{*}{$\begin{array}{l}\text { At } 3 \text { and } 6 \text { months after the CR, the SGT group produced higher } \\
\text { amount of non-stimulated ( } \mathrm{p}=0.036 \text { and } \mathrm{p}=0.001) \text { stimulated saliva } \\
(\mathrm{p}=0.002 \text { and } \mathrm{p}=0.003) \text { ) The incidence of xerostomia was lower in } \\
\text { the SGT group after } 3 \text { and } 6 \text { months from the radiotherapy }(\mathrm{p}=0.038 \\
\text { e } \mathrm{p}=0.017) \text {. After } 6 \text { months, there was no significant difference be- } \\
\text { tween the groups regarding palate alterations }(\mathrm{p}=0.548) \text {, swallowing } \\
\text { ( } \mathrm{p}=0.305 \text { ) and phonation }(\mathrm{p}=0.092) \text {. }\end{array}$} \\
\hline & $\mathrm{CR}+$ pilocarpine $(\mathrm{n}=60)$ & & \\
\hline & 54-70Gy & & \\
\hline \multirow[t]{3}{*}{$\begin{array}{l}\text { Liu et al. } \\
\text { [53] }\end{array}$} & CR $(n=34)$ & \multirow[t]{3}{*}{$\begin{array}{l}\text { Surgeries performed } 2 \\
\text { weeks before the CR. }\end{array}$} & \multirow{3}{*}{$\begin{array}{l}\text { At } 3 \text { and } 60 \text { months after the CR, the incidence of mild and severe } \\
\text { xerostomia in the control group was of } 76.5 \% \text { and } 78.6 \% \text { and in the } \\
\text { SGT group of } 13.9 \% \text { and } 12.9 \% \text {, respectively }(\mathrm{p}=0.000) \text {. The volume } \\
\text { of saliva was higher in the SGT group after } 3 \text { and } 60 \text { months from the } \\
\text { CR, with significant difference in comparison to the control group } \\
\text { (p<.0001). }\end{array}$} \\
\hline & $\mathrm{CR}+\mathrm{SGT}(\mathrm{n}=36)$ & & \\
\hline & 60-70 Gy & & \\
\hline \multirow{4}{*}{$\begin{array}{l}\text { Rieger et al. } \\
\quad[58]\end{array}$} & $\mathrm{CR}+\mathrm{SGT}(\mathrm{n}=36)$ & \multirow{4}{*}{$\begin{array}{l}\text { Surgery performed previ- } \\
\text { ously to the beginning of } \\
\text { the CR. }\end{array}$} & \multirow{4}{*}{$\begin{array}{l}\text { In the first } 6 \text { months, the patients who underwent SGT presented } \\
\text { better results, with significant difference in comparison to pilocar- } \\
\text { pine group (dysphagia, } p<0.001 \text {; xerostomia, } \mathrm{p}=0.001 \text {; viscous saliva, } \\
\mathrm{p}=0.03 \text { ). After one year, the SGT group sustained better results in } \\
\text { comparison to the pilocarpine group. }\end{array}$} \\
\hline & $\mathrm{CR}+$ pilocarpine $(\mathrm{n}=33)$ & & \\
\hline & $54-70$ Gy & & \\
\hline & $\begin{array}{l}80 \% \text { of the major salivary glands } \\
\text { (parotid) were included in the } \\
\text { radiation field with } \geq 50 \mathrm{~Gy}\end{array}$ & & \\
\hline \multirow{2}{*}{$\begin{array}{l}\text { Zhang et al. } \\
\text { [54] }\end{array}$} & $C R(n=14)-40-60$ Gy & \multirow{2}{*}{$\begin{array}{l}\text { Surgery performed } 1-2 \\
\text { months before the CR. }\end{array}$} & \multirow{2}{*}{$\begin{array}{l}\text { Salivary flow in the control group drastically dropped shortly after the } \\
\text { radiotherapy. There was significant difference between the groups in } \\
\text { salivary flow in resting and under stimulation } 1,3,6 \text { and } 12 \text { months } \\
\text { after the CR }(p \leq 0.006) \text {. SGT did not prevent dysphagia. }\end{array}$} \\
\hline & CR + SGT $(n=24)-50-70 \mathrm{~Gy}$ & & \\
\hline \multirow{3}{*}{$\begin{array}{l}\text { Zhang et al. } \\
\text { [59] }\end{array}$} & CR (n=33) & \multirow{3}{*}{$\begin{array}{l}\text { Surgery performed previ- } \\
\text { ously to the beginning of } \\
\text { the CR. }\end{array}$} & \multirow{3}{*}{$\begin{array}{l}\text { Three, } 6 \text { and } 12 \text { months after radiotherapy, the SGT group showed } \\
\text { lower incidence of mild and severe xerostomia, significantly differing } \\
\text { from the control group }(\mathrm{p}<0.001) \text {. The symptoms continued to dimin- } \\
\text { ish along the time. Five years after the CR, patients of the SGT group } \\
\text { presented salivary flow superior to the ones of the control group } \\
\qquad(\mathrm{p}<0.001) .\end{array}$} \\
\hline & $\mathrm{CR}+\mathrm{SGT}(\mathrm{n}=32)$ & & \\
\hline & 65-75 Gy & & \\
\hline
\end{tabular}

CR: Conventional Radiotherapy; SGT: Submandibular Gland Transfer.

\section{Discussion}

Radiotherapy frequently causes irreversible damages to salivary glands, and xerostomia is one of the most frequent complaints of patients irradiated on head and neck region. In the present review, resources capable of preventing radiotherapyinduced xerostomia were considered, because a prophylactic approach can save recovery time and medical care, spare the patients from physical and emotional exhaustion, as well as being less burdensome to patients and health care services. Preventive pharmacological methods were approached, such as the use of cholinergic agonists (pilocarpine and bethanechol), antioxidant substances, acupuncture, LLLT and submandibular gland transfer. Bethanechol and pilocarpine are muscarinic agonist drugs whose effect on salivary dysfunctions treatment is well established $[19,24,25]$. Pilocarpine, although widely studied in the prevention of radiotherapy-induced xerostomia, presents controversial results. While Zimmermann et al [27]. and Haddad \& Karimi [28] evidenced positive results of this drug in the prevention of salivary dysfunctions, Warde et al [31]. and Burlage et al [20]. demonstrated no preservation of glandular function in irradiated patients. As to bethanechol, even though the results are positive, only two clinical trials assessed its effect in the prevention of radiotherapy-induced xerostomia [19,2545]. Amifostine is the most widely used drug for the prevention of xerostomia in patients irradiated on head and neck regions due to its antioxidant properties [18,23,33,51,53]. However, the results of these studies are also controversial. For 
Buntzel et al [55]. and Brizel et al [5]. amifostine was effective in the control of xerostomia, but Jellema et al [35]. showed preservation of glandular function only in the first 6 months of evaluation. On the other hand, Rudat et al [5]. and Gu et al [33]. believe in the late effect of amifostine against radiotherapy-induced xerostomia. Regarding vitamin E, two clinical trials demonstrated satisfactory results in the prevention of radiotherapy-induced salivary dysfunctions $[35,42]$. As to resveratrol, there are no clinical results, once the studies were conducted only in animal models [28,34]. The SGT has presented good results regarding the prevention of xerostomia in patients who underwent radiotherapy $[53,54]$. Nonetheless, not all of the patients are eligible for this kind of procedure, such as patients with level I neck and ganglia involvement in both sides. Clinical trials also corroborate the efficiency of acupuncture to prevent radiotherapy-induced xerostomia. However, besides being scarce and heterogeneous, it is impossible to make double-blind studies with this technique. The low level laser therapy, even if still little studied in prevention of radiotherapy-induced xerostomia, has presented positive results in animals and in humans $[23,47$ 49], suggesting it might be used as a preventive method for xerostomia in patients who undergo radiotherapy. At this point in time, however, there is no procedure or drug capable of completely preventing the development of radiotherapy-induced xerostomia and hyposalivation. Controlled clinical trials are yet necessary in order to find therapeutic modalities that preserve the structure of the salivary glands exposed to ionizing radiation, preventing the occurrence of hyposalivation and xerostomia.

\section{References}

1. Duarte VM, Liu YF, Rafizadeh S, Tajima T, Nabili V, et al. (2013) Comparison of dental health of patients with head and neck cancer receiving imrt vs conventional radiation. Otolaryngol Head and Neck Surg 150(1): 81-86

2. Marta GN, Silva V, Carvalho HDA, de Arruda FF, Hanna SA, et al. (2014) Intensity-modulated radiation therapy for head and neck cancer: Systematic review and meta-analysis. Radiother Oncol 110(1): 9-15.

3. Li J, Shan Z, Ou G, Liu X, Zhang C, et al. (2005) Structural and functional characteristics of irradiation damage to parotid glands in the miniature pig. Int J Radiat Oncol Biol Phys 62(5): 1510-1516.

4. Murdoch Kinch CA, Kim HM, Vineberg KA, Ship JA, Eisbruch A (2008) Dose-effect relationships for the submandibular salivary glands and implications for their sparing by intensity modulated radiotherapy. Int J Radiat Oncol Biol Phys 72(2): 373-382.

5. Brizel DM, Wasserman TH, Henke M, Strnad V, Rudat V, et al. (2000) Phase III randomized trial of amifostine as a radioprotector in head and neck cancer. J Clin Oncol 18(19): 3339-3345.

6. Roesink JM, Moerland MA, Battermann JJ, Hordijk GJ, Terhaard CHJ (2001) Quantitative dose-volume response analysis of changes in parotid gland function after radiotheraphy in the head-and-neck region. Int J Radiat Oncol Biol Phys 51(4): 938-946.

7. Coppes RP, Vissink A, Konings AWT (2002) Comparison of radiosensitivity of rat parotid and submandibular glands after different radiation schedules. Radiother Oncol 63(3): 321-328.

8. Boraks G, Tampelini FS, Pereira KF, Chopard RP (2008) Effect of ionizing radiation on rat parotid gland. Braz Dent J 19(1): 73-76.

9. Tuji FM, Pontual ML, Barros SP, Almeida SM de, Bóscolo FN (2010)
Ultrastructural assessment of the radioprotective effects of sodium selenite on parotid glands in rats. J Oral Sci 52(3): 369-375.

10. Xu L, Yang X, Cai J, Ma J, Cheng H, et al. (2013) Resveratrol attenuates radiation-induced salivary gland dysfunction in mice. Laryngoscope 123(11): E23-E29.

11. Motallebnejad M, Abedi SM, Seyedmajidi M, Moghadamnia AA Ashrafpour M, et al. (2014) Evaluation of protective effect of propolis on parotid salivary glands in gamma-irradiated rats. J Contemp Dent Pract 15(1): 8-11.

12. Abedi SM, Yarmand F, Motallebnejad M, Seyedmajidi M, Moslemi D, et al. (2015) Vitamin E protects salivary glands dysfunction induced by ionizing radiation in rats. Arch Oral Biol 60(9): 1403-1409.

13. Eisbruch A, Ten Haken R, Kim H, Marsh L, Ship J (1999) Dose, volume, and function relationships in parotid salivary glands following conformal and intensity-modulated irradiation of head and neck cancer. Int J Radiat Oncol Biol Phys 45(3): 577-587.

14. Konings A, Cotteleer F, Faber H, van Luijk P, Meertens H, et al. (2005) Volume effects and region-dependent radiosensitivity of the parotid gland. Int J Radiat Oncol Biol Phys 62(4): 1090-1095.

15. Buentzel J, Micke O, Adamietz I, Monnier A, Glatzel M, et al. (2006) Intravenous amifostine during chemoradiotherapy for head-and-neck cancer: A randomized placebo-controlled phase III study. Int J Radiat Oncol Biol Phys 64(3): 684-691.

16. Simsek G, Gurocak S, Karadag N, Karabulut AB, Demirtaș E, et al. (2012) Protective effects of resveratrol on salivary gland damage induced by total body irradiation in rats. Laryngoscope 122(12): 2743-2748.

17. Chung MK, Kim DH, Ahn YC, Choi JY, Kim EH, et al. (2016) Randomized trial of vitamin C/E complex for prevention of radiation-induced xerostomia in patients with head and neck cancer. Otolaryngol Head Neck Surg 155(3): 423-430.

18. Ramos FM, Pontual ML, Almeida SM, Bóscolo F, Tabchoury C, et al. (2006) Evaluation of radioprotective effect of vitamin $\mathrm{E}$ in salivary dysfunction in irradiated rats. Arch Oral Biol 51(2): 96-101.

19. Jham BC, Teixeira IV, Aboud CG, Carvalho AL, Coelho M, et al. (2007) A randomized phase III prospective trial of bethanechol to prevent radiotherapy-induced salivary gland damage in patients with head and neck cancer. Oral Oncol 43(2): 137-142.

20. Burlage F, Roesink J, Kampinga H, Coppes RP, Terhaard C, et al. (2008) Protection of salivary function by concomitant pilocarpine during radiotherapy: a double-blind, randomized, placebo-controlled study. Int J Radiat Oncol Biol Phys 70(1): 14-22.

21. Jha N, Seikaly H, Harris J, Williams D, Liu R, et al. (2003) Prevention of radiation induced xerostomia by surgical transfer of submandibular salivary gland into the submental space. Radiother Oncol 66(3): 283289.

22. Braga F, Lemos Junior CA, Alves FA, Migliari DA (2011) Acupuncture for the prevention of radiation-induced xerostomia in patients with head and neck cancer. Braz Oral Res 25(2): 180-185.

23. Acauan MD, Gomes A, Braga Filho A, de Figueiredo MAZ, Cherubini K, et al. (2015) Effect of low-level laser therapy on irradiated parotid glandsstudy in mice. J Biomed Opt 20(10): 108002.

24. Gorsky M, Epstein JB, Parry J, Epstein MS, Le ND, et al. (2004) The efficacy of pilocarpine and bethanechol upon saliva production in cancer patients with hyposalivation following radiation therapy. Oral Surg Oral Med Oral Pathol Oral Radiol Endod 97(2): 190-195.

25. Jaguar GC, Lima ENP, Kowalski LP, Pellizzon AC, Carvalho AL, et al. (2015) Double blind randomized prospective trial of bethanechol in the prevention of radiation-induced salivary gland dysfunction in head and neck cancer patients. Radiother Oncol 115(2): 253-256. 
26. Cooper N, Gilbert JC, Gristwood RW, Wyllie MG (2015) Use of bethanechol for treatment of xerostomia.

27. Zimmerman RP, Mark RJ, Tran LM, Juillard GF (1997) Concomitant pilocarpine during head and neck irradiation is associated with decreased posttreatment xerostomia. Int J Radiat Oncol Biol Phys 37(3): 571-575.

28. Haddad P, Karimi M (2002) A randomized, double-blind, placebocontrolled trial of concomitant pilocarpine with head and neck irradiation for prevention of radiation-induced xerostomia. Radiother Oncol 64(1): 29-32.

29. Yang W, Liao G, Hakim SG, Ouyang D, Ringash J,et al. (2016) Is pilocarpine effective in preventing radiation-induced xerostomia? A systematic review and meta-analysis. Int J Radiat Oncol Biol Phys 94(3): 503-511.

30. Wiseman LR, Faulds D (1995) Oral Pilocarpine: A review of its pharmacological properties and clinical potential in xerostomia. Drugs 49(1): 143-155.

31. Warde P, Sullivan OB, Aslanidis J, Kroll B, Lockwood G, et al. (2002) A Phase III placebo-controlled trial of oral pilocarpine in patients undergoing radiotherapy for head-and-neck cancer. Int J Radiat Oncol Biol Phys 54(1): 9-13.

32. http://www.fda.gov/drugs/developmentapprovalprocess/ h o w d r u g s a r e d e v e lo ped a n d a p p r o ved/ drugandbiologicapprovalreports/ucm081869.htm. Accessed November 16,2016

33. Gu J, Zhu S, Li X, Wu H, Li Y, et al. (2014) Effect of amifostine in head and neck cancer patients treated with radiotherapy: A systematic review and meta-analysis based on randomized controlled trials. PLoS One 9(5): e95968.

34. Rades D, Fehlauer F, Bajrovic A, Mahlmann B, Richter E, et al. (2004) Serious adverse effects of amifostine during radiotherapy in head and neck cancer patients. Radiother Oncol 70(3): 261-264.

35. Jellema AP, Slotman BJ, Muller MJ, Leemans CR, Smeele LE, et al. (2006) Radiotherapy alone, versus radiotherapy with amifostine 3 times weekly, versus radiotherapy with amifostine 5 times weekly. Cancer 107(3): 544-553

36. Bukowski R (1996) Amifostine (Ethyol®): Dosing, administration and patient management guidelines. Eur J Cancer 32 A Suppl 4: S46-S49.

37. Gosselin TK, Mautner B, Wilkinson K (2002) Amifostine as a Radioprotectant. Clin J Oncol Nurs 6(3): 175-176.

38. Koukourakis MI (2003) Amifostine: Is there evidence of tumor protection? Semin Oncol 30(6 Suppl 18): 18-30.

39. Sert C, Celik MS, Akdag Z, Ketani MA, Nergiz Y (2000) The radioprotective effect of vitamins C, E and vitamin E + glutathione on the small intestine and the thyroid gland in rats irradiated with X-rays. Turkish J Med Sci 30(5): 417-425.

40. Gomes CC, Ramos Perez FM, Perez DE, Novaes PD, Boscolo FN, et al. (2013) Radioprotective effect of vitamin e in parotid glands: a morphometric analysis in rats. Braz Dent J 24(3): 183-187.

41. Singh VK, Singh PK, Wise SY, Posarac A, Fatanmi OO (2012) Radioprotective properties of tocopherol succinate against ionizing radiation in mice. J Radiat Res 54(2): 210-220.

42. Chitra S, Shyamala Devi C (2008) Effects of radiation and $\alpha$-tocopherol on saliva flow rate, amylase activity, total protein and electrolyte levels in oral cavity cancer. Indian J of Dent Res 19(3): 213-218.

43. Marques FZ, Markus MA, Morris BJ (2009) Resveratrol: Cellular actions of a potent natural chemical that confers a diversity of health benefits. Int J Biochem Cell Biol 41(11): 2125-2128.
44. Li J, Feng L, Xing Y, Wang Y, Du L, et al. (2014) Radioprotective and antioxidant effect of resveratrol in hippocampus by activating sirt1. Int ] Mol Scis 15(4): 5928-5939.

45. Zhuang L, Yang Z, Zeng X, Zhua X, Chen Z, et al. (2012) The preventive and therapeutic effect of acupuncture for radiation-induced xerostomia in patients with head and neck cancer: A systematic review. Integr Cancer Ther 12(3): 197-205.

46. Meng Z, Garcia MK, Hu C, Chiang J, Chambers M, et al. (2012) Randomized controlled trial of acupuncture for prevention of radiation-induced xerostomia among patients with nasopharyngeal carcinoma. Cancer 118(13): 3337-3344.

47. Gonnelli FAS, Palma LF, Giordani AJ, Deboni AL, Dias RS, et al. (2016) Low-level laser therapy for the prevention of low salivary flow rate after radiotherapy and chemotherapy in patients with head and neck cancer. Radiol Bras 49(2): 86-91.

48. Gonnelli FAS, Palma LF, Giordani AJ, Deboni AL, Dias RS, et al. (2016) Low-level laser for mitigation of low salivary flow rate in head and neck cancer patients undergoing radiochemotherapy: A prospective longitudinal study. Photomed Laser Surg 34(8): 326-330.

49. Lopes CO, Mas JRI, Zângaro RA (2006) Prevenção da xerostomia e da mucosite oral induzidas por radioterapia com uso do laser de baixa potência. Radiol Bras 39(2): 131-136.

50. Jha N, Seikaly H, McGaw T, Coulter L (2000) Submandibular salivary gland transfer prevents radiation-induced xerostomia. Int J Radiat Oncol Biol Phys 46(1): 7-11.

51. Sood AJ, Fox NF, O Connell BP, Lovelace TL, Nguyen SA, et al. (2014) Salivary gland transfer to prevent radiation-induced xerostomia: A systematic review and meta-analysis. Oral Oncol 50(2): 77-83.

52.Wu F, Weng S, Li C, Sun J, Li L, et al. (2015) Submandibular gland transfer for the prevention of postradiation xerostomia in patients with head and neck cancer: A systematic review and meta-analysis. ORL J Otorhinolaryngol Relat Spec 77(2): 70-86.

53. Liu XK, Su Y, Jha N, Hong MH, Mai HQ et al. (2011) Submandibular salivary gland transfer for the prevention of radiation-induced xerostomia in patients with nasopharyngeal carcinoma: 5-Year outcomes. Head Neck 33(3): 389-395.

54.Zhang Y, Guo CB, Zhang L, Wang Y, Peng X, et al. (2012) Prevention of radiation-induced xerostomia by submandibular gland transfer. Head Neck 34(7): 937-942.

55. Büntzel J, Kuttner K, Frohlich D, Glatzel M (1998) Selective cytoprotection with amifostine in concurrent radiochemotherapy for head and neck cancer. Ann Oncol 9(5): 505-509.

56. Seikaly H, Jha N, Harris JR, Barnaby P, Liu R, et al. (2004) Longterm outcomes of submandibular gland transfer for prevention of postradiation xerostomia. Arch Otolaryngol Head Neck Surg 130(8): 956-961.

57. Jha N, Seikaly H, Harris J, Williams D, Sultanem K, et al. (2009) Phase III randomized study: Oral pilocarpine versus submandibular salivary gland transfer protocol for the management of radiation-induced xerostomia. Head Neck 31(2): 234-243.

58. Rieger JM, Jha N, Lam Tang JA, Harris J, Seikaly H (2012) Functional outcomes related to the prevention of radiation-induced xerostomia: Oral pilocarpine versus submandibular salivary gland transfer. Head Neck 34(2): 168-174.

59. Zhang X, Liu F, Lan X, Yu L, Wu W, et al. (2014) Clinical observation of submandibular gland transfer for the prevention of xerostomia after radiotherapy for nasopharyngeal carcinoma: A prospective randomized controlled study of 32 cases. Radiat Oncol 9: 62 . 


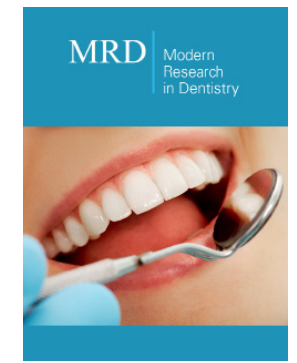

\section{Modern Research in Dentistry}

\section{Benefits of Publishing with us}

- High-level peer review and editorial services

- Freely accessible online immediately upon publication

- Authors retain the copyright to their work

- Licensing it under a Creative Commons license

- Visibility through different online platforms 